\title{
FAILURE OF NITRIC OXIDE PRODUCTION BY MACROPHAGES AND DECREASE IN CD4+ $T$ CELLS IN ORAL PARACOCCIDIOIDOMYCOSIS: POSSIBLE MECHANISMS THAT PERMIT LOCAL FUNGAL MULTIPLICATION
}

\author{
Aline Carvalho BATISTA(1), Cleverson Teixeira SOARES(2) \& Vanessa Soares LARA(3)
}

\begin{abstract}
SUMMARY
Paracoccidioidomycosis is a chronic granulomatous disease that induces a specific inflammatory and immune response. The participation of nitric oxide (NO), a product of the inducible nitric oxide synthase enzyme (iNOS), as an important fungicidal molecule against Paracoccidioides brasiliensis has been demonstrated. In order to further characterize the Oral Paracoccidioidomycosis (OP), we undertook an immunohistochemical study of iNOS ${ }^{+}, \mathrm{CD}_{4} \mathrm{RO}^{+}, \mathrm{CD}^{+}, \mathrm{CD}^{+}, \mathrm{CD}^{2} 0^{+}, \mathrm{CD} 68^{+}$ cells and mast cells. The samples were distributed in groups according to the number of viable fungi per $\mathrm{mm}^{2}$. Our results showed weak immunolabeling for iNOS in the multinucleated giant cells (MNGC) and in most of the mononuclear (MN) cells, and the proportion of iNOS ${ }^{+} \mathrm{MN} / \mathrm{MNGC}$ cells in the OP were comparable to Control (clinically healthy oral tissues). Additionally, our analysis revealed a similarity in the number of $\mathrm{CD}^{+}$cells between the Control and the OP groups with higher numbers of fungi. These findings suggest that a low expression of iNOS and a decrease in the CD4 ${ }^{+} \mathrm{T}$ cells in OP may represent possible mechanisms that permit the local fungal multiplication and maintenance of active oral lesions.
\end{abstract}

KEYWORDS: Paracoccidioidomycosis; Nitric oxide; Immune cells.

\section{INTRODUCTION}

Paracoccidioides brasiliensis (P. brasiliensis) causes a chronic granulomatous mycosis prevalent in the subtropical and wet regions of Latin America, and cell-mediated immunity represents the main mode of protection against this fungal infection ${ }^{13,15,22,23,33,36}$.

The course of disease varies from patient to patient and there are two main clinical forms: the acute form or juvenile type and the chronic form or adult type. Both forms are associated with systemic infection and an abnormal cell-mediated immune response $e^{5,22,23,28,30,32,33}$. Adult paracoccidioidomycosis primarily afflicts the lungs, leading to significant impairment of function. Subsequently, the disease can disseminate to other organs and tissues, forming secondary lesions in the mucous membranes (oral or nasal), skin, lymph nodes and adrenal glands ${ }^{7}$. However, reports of Oral Paracoccidioidomycosis (OP) are rare, generally involving the gingiva, alveolar process or palate ${ }^{2,6}$, and few reports have described the local immune response at these sites $^{29,32}$, which may be different to that at other sites such as skin or lung.

In paracoccidioidomycosis, the macrophages form the major cell defense against this pathogen ${ }^{21}$. However, macrophage function depends upon their state of activation, which endows them with microbicidal activity $^{12}$. The variable susceptibility of mice and humans to develop the disease $e^{3,5}$, which probably has a genetic basis ${ }^{10}$, appears to be explained by an imbalance in the secretion of cytokines that downregulates the host cellular immune response ${ }^{5}$ and leads to hyporesponsiveness of susceptible macrophages ${ }^{3}$. Resistance in mice is linked to a preferential T-helper 1 (Th1) immune response, with elevated secretion of interferon- $\gamma$ (IFN- $\gamma$ ) and interleukin-2 (IL-2) $)^{35,36}$, and susceptibility is associated with very low levels of these cytokines ${ }^{16}$, which might implicate in reduced fungicidal activity.

Both IFN- $\gamma$ and tumor necrosis factor- $\alpha$ (TNF- $\alpha)$ apparently confer resistance to $P$. brasiliensis by stimulating granuloma formation and nitric oxide (NO) production ${ }^{7,21,36}$. In contrast, transforming growth factor$\beta$ (TGF- $\beta$ ) and Th2 type cytokines, especially interleukin-10 (IL-10), inhibit nitric oxide synthase (NOS) induction in macrophages ${ }^{18,19}$. The expression of the inducible nitric oxide synthase enzyme (iNOS) is a response to an inflammatory stimulus and it results in a large amount of NO, which appears to inhibit the transformation of $P$. brasiliensis conidia to yeast but probably has the secondary effect of inducing the immunosuppressive state noted in murine paracoccidioidomycosis ${ }^{7,21}$. This immunosuppression is manifested by a decrease in Ia antigen expression and a depression of the immunoproliferative response $e^{1,7,8,21,34}$. Evidence from a recent study suggests that $\mathrm{NO}$ is involved in the induction of $\mathrm{T}$ cell immunosuppression during infection as well as in the killing of P. brasiliensis ${ }^{31}$.

(1) Department of Stomatology (Oral Pathology), Dental School, Federal University of Goiás, Goiânia, Goiás, Brazil.

(2) Member of the Institute of Anatomopathology and Cytopathology of Bauru and of the Lauro Souza Lima Institute of Dermatological Diseases, Bauru, São Paulo, Brazil.

(3) Department of Stomatology (Oral Pathology), Bauru Dental School, University of São Paulo, Bauru, São Paulo, Brazil.

Correspondence to: Vanessa Soares Lara, Rua Caetano Sampieri 4-25, apto 72, Edifício Barcelona, Vila Universitária, $17012-460$ Bauru, SP, Brazil, Phone/Fax: +55.62.3521-1886, E-mails: vanessa@fob.usp.br and ali.caba@uol.com.br 
BATISTA, A.C.; SOARES, C.T. \& LARA, V.S. - Failure of nitric oxide production by macrophages and decrease in CD4+ T cells in oral paracoccidioidomycosis: possible mechanisms that permit local fungal multiplication. Rev. Inst. Med. trop. S. Paulo, 47(5): 267-273, 2005.

In an attempt to better characterize the oral lesions of paracoccidioidomycosis and the cell-mediated immune reactivity of the host, we identified and quantified the expression of iNOS, CD3, CD8, CD45RO, CD68, CD20 and mast cell tryptase, in samples of human oral paracoccidioidomycosis, via immunohistochemistry. In addition, the relationship between the number of viable yeast cells in the OP lesions and the expression of iNOS and different subpopulations of cells was determined.

\section{MATERIAL AND METHODS}

Samples: The samples were obtained and selected from biopsies in the files of the Anatomical Pathology Laboratory of the Department of Stomatology, Bauru Dental School, University of São Paulo, Brazil and of the Institute of Anatomopathology and Cytopathology of Bauru (ANATOM), Brazil. A total of 20 cases of the chronic form of human oral paracoccidioidomycosis and eight of human clinically healthy oral tissues (Control) were used in this study.

All the patients were Brazilian, most were adult males (seventeen males and three females ranging in age from 32 to 79 years) with no history of drug abuse or HIV-positive status. The biopsies were obtained before the beginning of treatment for diagnostic purposes. Pulmonary changes were described in twelve cases. Table 1 presents the sites affected by paracoccidioidomycosis lesions in the cases studied.

Table 1

Characteristics of study group and sites affected by paracoccidioidomycosis lesions

\begin{tabular}{llll}
\hline Sex & Age & Race & Oral involvement \\
\hline M & 63 & White & Posterior maxillary gingiva and lower lip \\
M & 32 & White & Cheek and maxillary alveolar process \\
M & 47 & White & Lateral tongue and floor of mouth \\
F & 38 & Not given & Lateral tongue \\
M & 70 & Black & Anterior maxillary gingiva and lower lip \\
M & 46 & White & Mandibular alveolar process, floor of \\
& & & mouth and lower lip \\
M & 48 & Black & Lateral tongue \\
M & 72 & White & Cheek and labial commissure \\
M & 52 & Black & Mandibular alveolar process, cheek, floor \\
& & & of mouth and palate \\
M & 76 & White & Palate \\
M & 49 & White & Gingiva \\
F & 51 & White & Anterior maxillary gingival \\
F & 44 & White & Mandibular alveolar process \\
M & 50 & White & Lateral tongue \\
M & 79 & White & Palate \\
M & 34 & Black & Lateral tongue \\
M & 65 & Black & Gingiva and floor of mouth \\
M & 46 & White & Gingiva and palate \\
M & 43 & White & Mandibular alveolar process and palate \\
M & 51 & White & Dorsal tongue \\
\hline
\end{tabular}

The control samples consisted of oral tissues that were obtained during dental extractions, generally of pre-molars, for orthodontic reasons, or included molars. Most of control patients were adult males (six males and two females ranging in age from 20 to 49 years). The samples were selected from a previous study of these slides stained with hematoxylin and eosin, prioritizing the most recent cases and best representative lesions presenting integrity and tissue arrangement. The samples underwent immunohistochemical study. This study was approved by the Institutional Review Board of Bauru Dental School, University of São Paulo (Protocol 137/2003).

Light microscopy: Diagnosis of paracoccidioidomycosis was made previously on the basis of microscopic analysis, from which $P$. brasiliensis may be identified scattered within the connective tissue or inside microabscesses as well as within macrophages and inflammatory giant cells, with the routine hematoxylin and eosin (HE) stain and, for a clearer demonstration, by the Grocott stain. The quantitative analysis of the viable fungi was carried out in all cases by Grocott stain and in high magnification (x800). The fungus was considered viable when its morphology was totally preserved and non-viable when it had the appearance of a shell-like, empty cell. When gemulating cells were present in our counting, these were considered a single yeast cell.

Antibodies: Rabbit anti-human iNOS (SC-651) polyclonal antibody was purchased from Santa Cruz Biotechnology (California, USA), and was used at a dilution of 1:500. Rabbit anti-human CD3 polyclonal antibody (A0452,) at 1:60, mouse anti-human CD8 monoclonal antibody (M7103) at 1:500, mouse anti-human CD45RO monoclonal antibody (M0742) at 1:500, mouse anti-human CD20 monoclonal antibody (M0755) at 1:80, mouse anti-human CD68 monoclonal antibody (M0876) at 1:200 and mouse anti-human mast cell tryptase monoclonal antibody (M7052), at 1:80, were purchased from DAKO (Glostrup, Denmark).

Immunohistochemistry: After embedding the tissues in paraffin wax, $3 \mu \mathrm{m}$ thick sections were obtained and collected on silane-coated glass slides (DAKO, S3003, Glostrup, Denmark). The immunohistochemical characterization of cells was performed using the immunoperoxidase (Avidin-Biotin-Peroxidase) method. The samples were deparaffined through immersion in xylene, and this was followed by immersion in alcohol and then incubation with 3\% hydrogen peroxide diluted in phosphate-buffered saline (PBS) for 40 minutes. Next, the sections were immersed in citrate buffer ( $\mathrm{pH}$ 6.0; SIGMA, P4809, St. Louis, USA) for 20 minutes at $95{ }^{\circ} \mathrm{C}$, except for the mouse anti-human CD20 antibody for which sections were immersed in 5\% trypsin. Soon afterward, the sections were blocked by incubation with $3 \%$ normal goat serum diluted in distilled water, at room temperature, for 20 minutes. Then, the slides were incubated with the primary antibodies at $4{ }^{\circ} \mathrm{C}$ overnight. All the antibodies were diluted in $1 \%$ PBS-BSA (bovine serum albumin). Serial tissue sections were used and each of the seven different antibodies was applied to a different section from the same block. Following incubation with the primary antibodies the sections were washed with PBS and incubated with biotinylated anti-mouse/rabbit/goat IgG antibodies (1:100 in 1\% PBSBSA) (DAKO, K0492) for 60 minutes at room temperature. Sections were then incubated with avidin-biotin complex (DAKO, K0492) for 45 minutes at room temperature, and were incubated in a solution of 5 mg 3,3'-Diaminobenzidine (SIGMA, D4293) diluted in $10 \mathrm{~mL}$ PBS containing $180 \mu \mathrm{L}$ of $\mathrm{H}_{2} \mathrm{O}_{2}(20 \mathrm{Vol}$.), for 20 to 30 minutes at room temperature. Following washing with distilled water, the slides were counterstained with Mayer's hematoxylin for five minutes. Negative controls were obtained by the omission of primary antibodies, which 
BATISTA, A.C.; SOARES, C.T. \& LARA, V.S. - Failure of nitric oxide production by macrophages and decrease in CD4 ${ }^{+}$T cells in oral paracoccidioidomycosis: possible mechanisms that permit local fungal multiplication. Rev. Inst. Med. trop. S. Paulo, 47(5): 267-273, 2005.

were substituted by $1 \%$ PBS-BSA and by non-immune rabbit (DAKO, X0902) or mouse (DAKO, X0910) serum.

Quantitative analysis of $\mathrm{CD3}^{+}, \mathrm{CD8}^{+}, \mathrm{CD}^{2} 5 \mathrm{RO}^{+}, \mathrm{CD68}^{+}, \mathrm{CD20}^{+}$ and mast cell tryptase-positive cells, and viable yeast cells: The number of viable yeast cells, of positively-stained cells $\left(\mathrm{CD}^{+}, \mathrm{CD}^{+}\right.$,

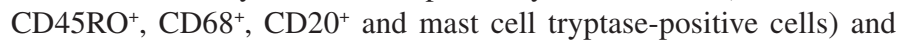
the total number of inflammatory cells and mononuclear and polymorphonuclear inflammatory cells was determined using an integration graticule (CARL ZEISS-4740680000000-Netzmikrometer 12.5x). All cells were enumerated in 20 consecutive microscopic highpower fields (x800) and, at this magnification, each field (integration graticule) has an area equal to $0.015625 \mathrm{~mm}^{2}$; thus, a total area equal to $0.3125 \mathrm{~mm}^{2}$ was analyzed in each specimen. The proportions of immunostained cells were obtained from the values for the total number of inflammatory cells and for the positive cells. The results are expressed as mean \pm standard deviation (SD) of $n$ observations, per $\mathrm{mm}^{2}$. The statistical study was performed using Analysis of Variance (ANOVA) followed by Tukey's test or by the unpaired, two-tailed $t$ test. A p value of less than 0.05 was considered to be statistically significant. The number of $\mathrm{CD} 4^{+}$cells was obtained through subtraction of the $\mathrm{CD}^{+}$cells by $\mathrm{CD}^{+}$cells in all samples. The cells positive for mast cell tryptase were considered to be mast cells.

Quantitative and Qualitative analysis of NOS $^{+}$cells: The relative proportions of iNOS immunoreactive cells were determined using the point-counting method by a 25-point integration graticule (CARL ZEISS, Germany) at x800 magnification. All counts were performed in 20 consecutive microscopic high power fields. The percentage of positive cells was calculated as the proportion of the total of the inflammatory cells and this result was verified using the non-parametric Kruskal Wallis test followed by Dunn's test or the Mann-Whitney test. The cell proportions were expressed as percentages (mean $\pm \mathrm{SD}$ ). A p value of less than 0.05 was considered to be statistically significant. The intensity of immunostaining and the morphology of the iNOS ${ }^{+}$ cells were also analyzed.

\section{RESULTS}

By means of routine HE staining followed by Grocott staining, the main microscopic characteristics of OP were observed. A granulomatous inflammatory disease was identified, characterized by the presence of aggregates of macrophages, epithelioid and multinucleated giant cells with lymphocytes, plasma cells, macrophages and polymorphonuclear (PMN) cells, surrounding central aggregates. The OP lesions comprised a mix of the compact/organized and disorganized granulomas in the same specimens.

The number of viable yeast cells in these lesions was highly variable (9.6 to 800 viable yeast cells per $\mathrm{mm}^{2}$ ) and, in accordance with the fungi number, the samples were distributed in groups: I (1-50 yeast cells per $\left.\mathrm{mm}^{2}\right)-\mathrm{n}=4$, II (51-100 yeast cells per $\left.\mathrm{mm}^{2}\right)$ - $\mathrm{n}=3$, III (101200 yeast cells per $\left.\mathrm{mm}^{2}\right)-\mathrm{n}=3$, IV $\left(201-400\right.$ yeast cells per $\left.\mathrm{mm}^{2}\right)-\mathrm{n}=$ 4 and $\mathrm{V}\left(401-800\right.$ yeast cells per $\left.\mathrm{mm}^{2}\right)-\mathrm{n}=6$.

$\mathrm{CD4}^{+}$cells are decreased in the oral paracoccidioidomycosis lesions with a higher number of viable yeast cells: In OP, macrophages and giant cells showing strong positive staining for anti-
CD68 represented $49.15 \%$ of the inflammatory infiltrate. In relation to the control group, the number of $\mathrm{CD} 8^{+}$cells increased significantly in OP. However, no difference was observed among OP groups considering the number of viable yeast cells per $\mathrm{mm}^{2}$ and $\mathrm{CD}^{+} 8^{+}$cells (Fig. 1 and 2).
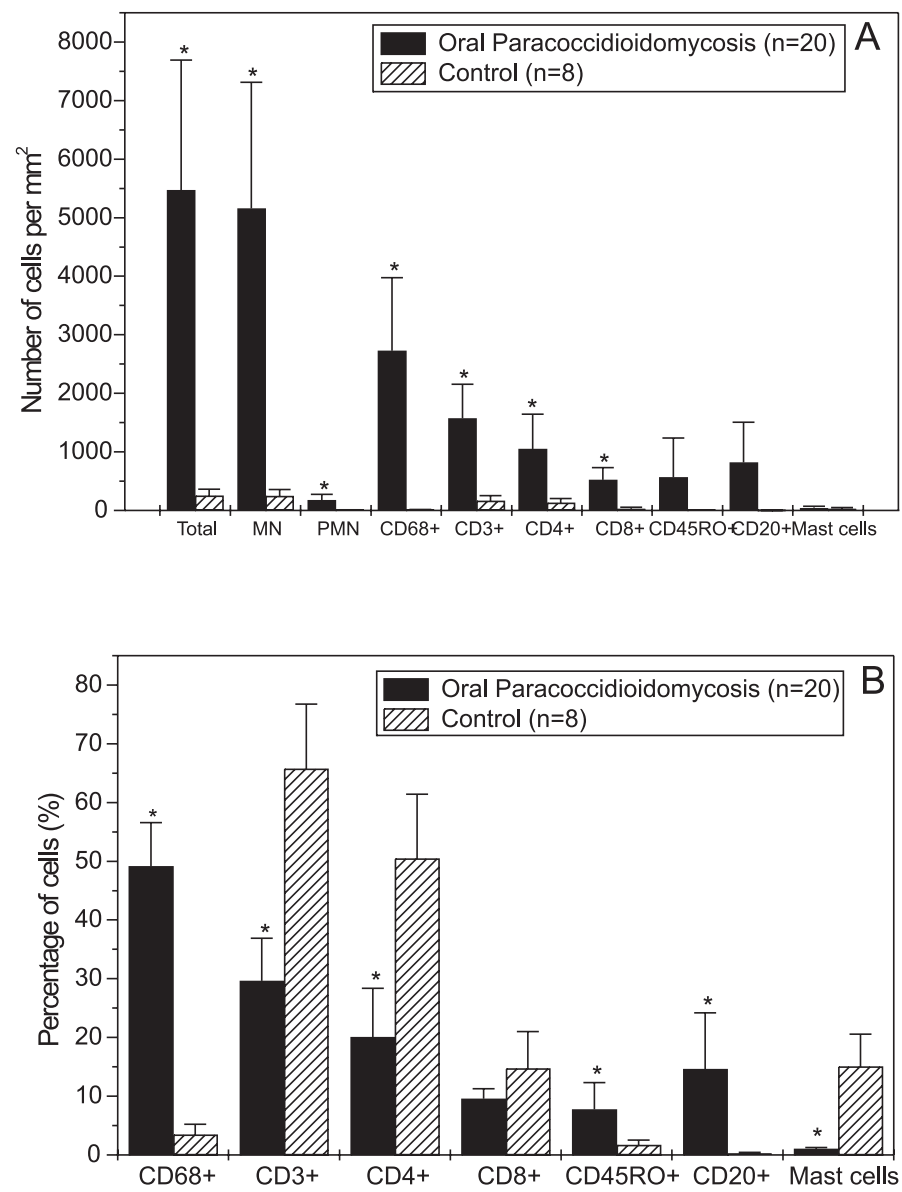

Fig. 1 - Total number of the inflammatory cells, MN cells, $\mathrm{PMN}$ cells, CD68 ${ }^{+}, \mathrm{CD}^{+}, \mathrm{CD}^{+}{ }^{+}$ $\mathrm{CD}^{+}, \mathrm{CD}_{5} 5 \mathrm{RO}^{+}, \mathrm{CD} 20^{+}$cells and mast cells in oral paracoccidioidomycosis lesions and in clinically healthy oral tissues (Control) (A). Percentage of immunostained cells in relation to the total inflammatory cells (B). Data are expressed as mean $\pm \mathrm{SD}, t$ test (A) and Mann Whitney test (B) $(* \mathrm{p}<0.05)$.

The inflammatory cells localized in the periphery of the granulomas were quantified with regard to $\mathrm{CD} 3, \mathrm{CD} 8, \mathrm{CD} 45 \mathrm{RO}, \mathrm{CD} 20$ and mast cell tryptase expression. The number of $\mathrm{CD}^{+}, \mathrm{CD}^{+}$and $\mathrm{CD} 8^{+}$cells increased significantly in OP when compared to Control (Fig. 1), but a quantitative microscopic analysis of these cellular phenotypes indicated that there were no significant differences between the OP groups (I, II, III, IV and V) (Fig. 2). However, when the OP groups were compared individually with the Control, it was found that the number of $\mathrm{CD}^{+}$ cells was not significantly increased in the OP groups with a higher number of fungal cells (IV and V groups) (Fig. 2). In OP samples, the number of $\mathrm{CD}^{+}$cells was inversely correlated with the number of fungal cells (Pearson correlation test, $\mathrm{r}=-0.59$ and $\mathrm{p}=0.0052$ ). Regarding the number of $\mathrm{CD}^{+}$cells, significant differences were observed only between the IV group and the Control (Fig. 2). 


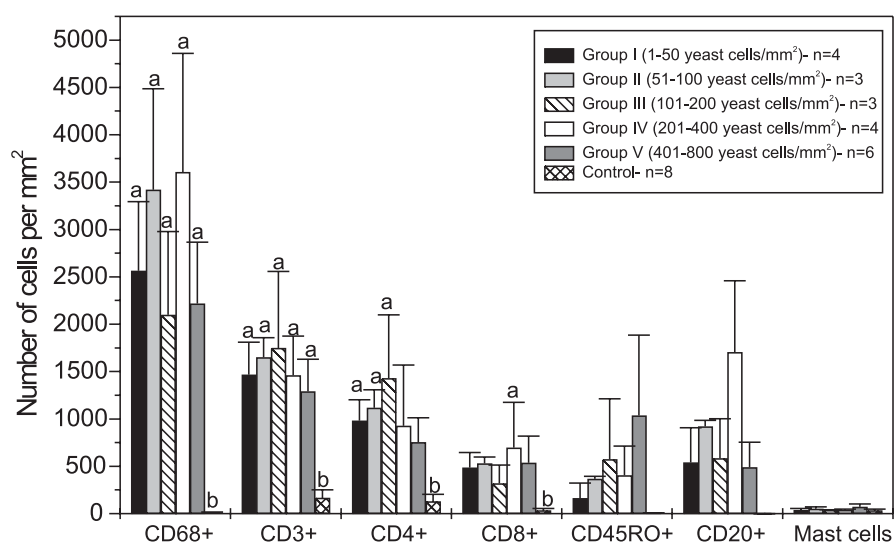

Fig. 2 - Number of $\mathrm{CD}^{+} 8^{+}, \mathrm{CD}^{+}, \mathrm{CD}^{+}, \mathrm{CD}^{+}, \mathrm{CD} 45 \mathrm{RO}^{+}, \mathrm{CD} 20^{+}$cells and mast cells in oral paracoccidioidomycosis lesions distributed according to the number of viable yeast cells per $\mathrm{mm}^{2}$, and in clinically healthy oral tissues (Control). Data are expressed as mean $\pm \mathrm{SD}$, ANOVA and Tukey's test ( $a$ and $b$ represent groups with statistically significant difference $\mathrm{p}<0.05)$.

The number of $\mathrm{CD} 45 \mathrm{RO}^{+}$and $\mathrm{CD} 20^{+}$cells was not significantly different in OP in relation to the Control, nor between the I, II, III, IV and V groups (Fig. 1 and 2). Mast cells were diffusely distributed and similar numbers of these cells were observed in all OP groups and the Control (Fig. 2).

Few of the MN cells from oral paracoccidioidomycosis lesions express iNOS, while all the PMNs show strong immunolabeling for this enzyme: The iNOS expression in OP groups was identified in mononuclear cells assumed to be macrophages, in MNGC and in PMN cells (Fig. 3). Considering the samples from the OP groups I to V, our results demonstrate similar percentages of total iNOS ${ }^{+}$cells, iNOS ${ }^{+}$ MN/MNGC cells and iNOS ${ }^{+}$PMN cells (Fig. 3). However, when iNOS expression in OP was compared with Control, iNOS ${ }^{+} \mathrm{PMN}$ cells were increased only in groups III, IV and V (samples with higher numbers of yeast cells) (Fig. 3).

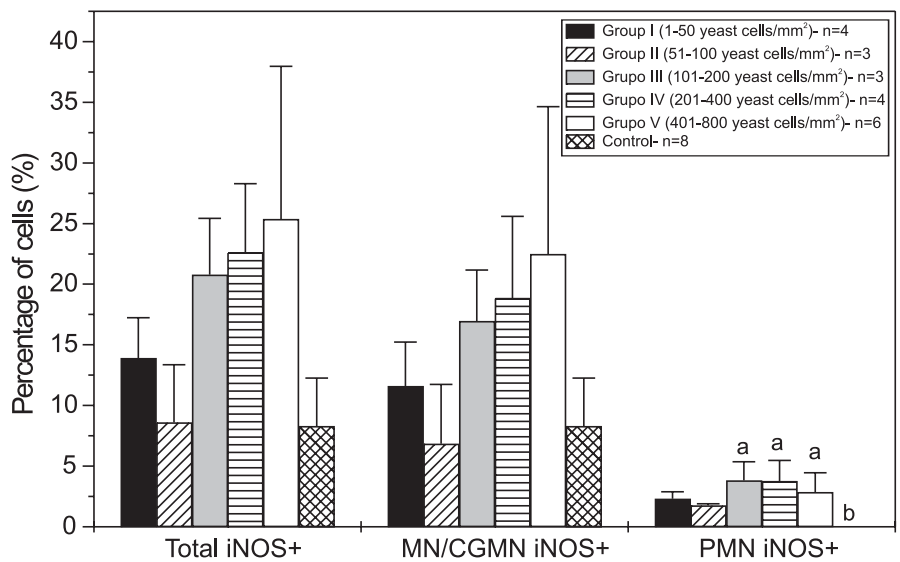

Fig. 3 - Percentage of iNOS ${ }^{+}$cells, iNOS ${ }^{+}$MN/ MNGC cells and iNOS ${ }^{+} \mathrm{PMN}$ cells in samples of clinically healthy oral tissues (Control) and of oral paracoccidioidomycosis distributed according to the number of viable yeast cells per $\mathrm{mm}^{2}$. Data are expressed as mean $\pm \mathrm{SD}$ (Kruskal-Wallis and Dunn's test; $a$ and $b$ represent groups with statistically significant difference $-\mathrm{p}<0.05)$.
A general analysis of OP indicated a weak immunolabeling for iNOS in the great majority of agglomerates of the epithelioid macrophages and MNGC cells, which was not noted when the nonimmune serum was used. In OP, strong iNOS expression was also observed in a few mononuclear cells localized around the granulomas. In addition, the immunohistochemical analysis revealed that only PMN cells exhibited an intense immunolabeling for iNOS. Almost all the PMNs found in the granulomas and microabscesses in the samples of OP were strongly iNOS ${ }^{+}$. Furthermore, a weak to moderate staining for iNOS was also exhibited by epithelial cells. The negative controls used for each reaction did not show any immunostaining, confirming the specificity of the procedure (Fig. 4).
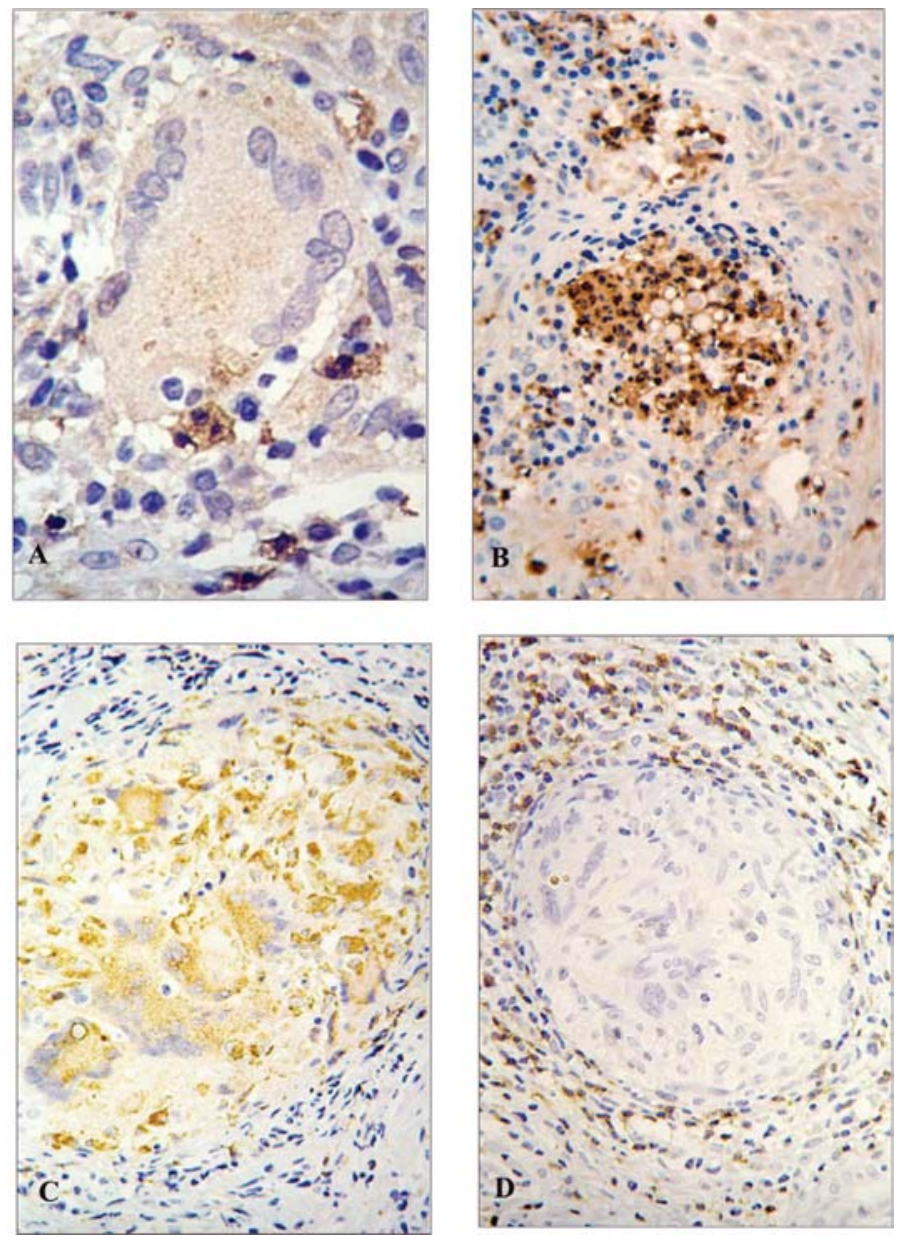

Fig. 4 - Weakly stained iNOS ${ }^{+}$MN/MNGC cells (A) and iNOS ${ }^{+} \mathrm{PMN}(\mathbf{B})$ with intense staining inside microabscesses in OP. C shows $\mathrm{CD}^{+} 8^{+}$cells labeled in central areas of the OP granuloma, and $\mathbf{D}$ shows $\mathrm{CD}^{+}$cells in the periphery of the granuloma in OP. Original magnification x12.5 (C and D), x25 (B) and x100 (A) (immunohistochemical staining).

Considering the relationship between the percentage of $\mathrm{CD}^{+} 8^{+}$cells and the percentage of iNOS ${ }^{+} \mathrm{MN} / \mathrm{MNGC}$ cells, we observed similar values for the former in OP groups. It was observed a positive correlation between the iNOS ${ }^{+}$MN/MNGC cells with in yeast cell number (Pearson correlation test, $\mathrm{p}=0.0035, \mathrm{r}=0.61$ ) (Fig. 5). Interestingly, a minority of the $\mathrm{CD}^{+} 8^{+}$cells were $\mathrm{iNOS}^{+}$, representing a median of $32 \%$ of the total number of $\mathrm{CD} 68^{+}$cells. 


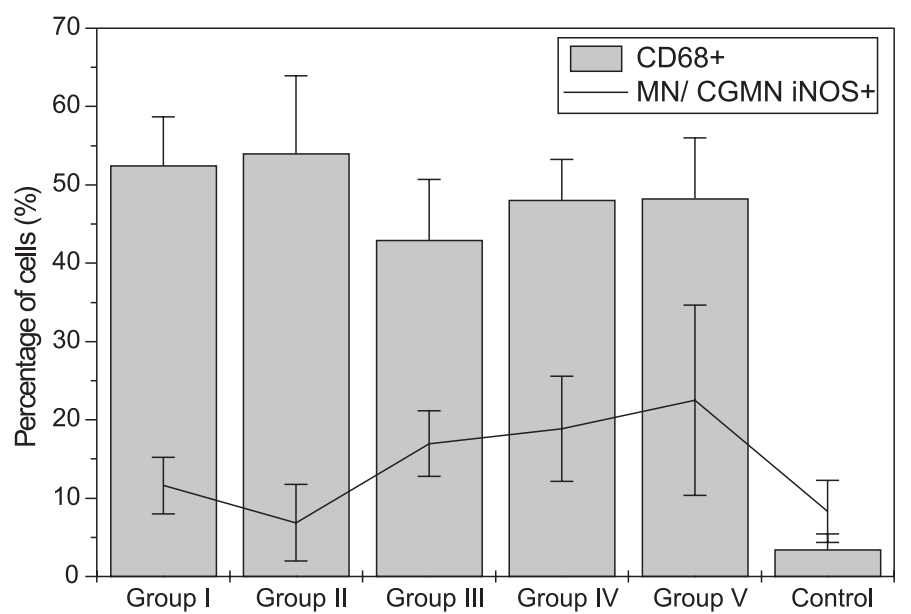

Fig. 5 - Comparison of the percentage of $\mathrm{CD}^{2} 8^{+}$cells and iNOS ${ }^{+} \mathrm{MN} / \mathrm{MNGC}$ cells in samples of clinically healthy gingival oral tissues (Control- $n=8)$ and of oral paracoccidioidomycosis distributed according to the number of viable yeast cells per $\mathrm{mm}^{2}$ (Groups: I-n $=4$, II- $\mathrm{n}=3$, $\mathrm{III}-\mathrm{n}=3, \mathrm{IV}-\mathrm{n}=4$ and V-n $=6$ ).

\section{DISCUSSION}

The balance between the T-cell response and consequent macrophage activation plays an important regulatory role in determining the outcome of $P$. brasiliensis infections in humans. Depending on their activation status, the macrophages may or may not be noxious to the parasites ${ }^{11,12,21}$. The mechanism of cytokines-induced fungicidal activity of human macrophages appears to involve the participation of $\mathrm{NO}^{21}$, which exerts a powerful cytostatic and cytotoxic effect against P. brasiliensis ${ }^{11,21}$. A failure of a specific T-cell response to activate macrophages in paracoccidioidomycosis may permit the multiplication and dissemination of the fungus including mucocutaneous manifestations. Our study presents some evidence to support this idea. First, we demonstrated weak immunostaining for iNOS in the central area of the OP granuloma including most of the epithelioid cells and MNGC, and a low percentage of strongly $\mathrm{iNOS}^{+}$macrophages in the periphery of OP granulomas. This weak immunostaining for iNOS has became more relevant since has been reported that macrophage, probably when adequately stimulated, are strongly positive for iNOS in tissues containing granulomas caused by Mycobacterium tuberculosis, Leishmania, Toxoplasma and Cryptococcus neoformans ${ }^{20}$. In a recent paper, NEWORAL et al. ${ }^{32}$ also demonstrated low numbers of iNOS ${ }^{+}$macrophages in oral lesions of paracoccidioidomycosis (adult form) that may represent a parasite-induced evasive mechanism allowing survival inside the host tissues.

Second, we observed a decrease in the number of $\mathrm{CD} 4^{+} \mathrm{T}$ cells in the OP lesions with higher numbers of viable yeast cells, and that the majority of the $\mathrm{CD} 68^{+}$cells were not iNOS ${ }^{+}$. On the basis of our results, we suggest that, in the oral granulomas of paracoccidioidomycosis, a low production of $\mathrm{NO}$ and/or functional inactivation of iNOS might be present, which might represent a reduction in macrophage activation. Although the different responses of individuals to infectious pathogens have been related to differential activation of $\mathrm{CD}^{+}$cells, a number of host-specific genetic factors can synergize with biologic tracts of pathogens to drive the susceptibility phenotype ${ }^{26}$.
Another interesting finding from our study is that there was an increase in the proportion of $\mathrm{CD} 20^{+}$cells in OP when compared to Control. In agreement with this, MAMONI et al. ${ }^{27}$ observed high production of specific $\operatorname{IgG} 4, \operatorname{IgE}$ and $\mathrm{IgA}$, in the disseminated form of human paracoccidioidomycosis.

In fact, the resistance to $P$. brasiliensis infection is associated with immune responses, which favor cellular immunity with activation of $\mathrm{CD}^{+} \mathrm{T}$ cells and macrophages ${ }^{10}$; however, $\mathrm{CD}^{+} \mathrm{T}$ cells depletion in susceptible mice impaired the clearance of yeasts from the lungs and increased the fungal dissemination to the liver and spleen ${ }^{16}$. Perhaps the low number of $\mathrm{CD}^{+} \mathrm{T}$ cells observed in our study in most of the OP groups may contribute to the failure of early control of the fungal multiplication and consequent mucocutaneous manifestation.

A recent experimental study indicates that the iNOS-derived NO is essential for resistance to paracoccidioidomycosis, but that high and continued NO production is associated with susceptibility ${ }^{31}$. Nevertheless, it is important to stress that the role of NO in human paracoccidioidomycosis is still unknown and may be different from that in mice. In vitro, relatively low concentrations of NO induce a strong and specific inhibition of $\mathrm{T}$ cell proliferation ${ }^{1,7,37}$, probably by means of Ia antigen expression inhibition in the macrophages ${ }^{7,34}$. In the present study, we found that almost all the PMNs found in the granulomas and microabscesses in the samples of OP were strongly iNOS $^{+}$. Our results also indicate an increase in the percentage of the iNOS ${ }^{+} \mathrm{PMNs}$ in the OP samples with higher numbers of yeast cells when compared to Control. Thus, the NO production by PMNs in these OP samples may contribute to the low number of $\mathrm{CD}^{+} \mathrm{T}$ cells observed in these same samples. We have previously reported an important expression of iNOS by PMNs in another chronic inflammatory disease ${ }^{4}$, ie. human periodontal disease, and we speculate that the NO production by PMNs may modulate the degree of inflammation ${ }^{24}$, inducing a strong and specific inhibition of $\mathrm{T}$ cell proliferation in both Th subsets ${ }^{37}$. Although the human periodontal disease does not represent a granulomatous lesion, the PMNs express more iNOS than MN cells as observed in the present study with OP. This expression of iNOS by PMNs in OP may represent an important source of NO. On the other hand, it could indicate merely cell activation and antifungal activity of PMNs.

Another possible hypothesis to explain the decrease in $\mathrm{CD} 4^{+} \mathrm{T}$ cells observed by us in OP samples could be the inhibition of specific chemokines production such as IP-10 and Mig, involved in the recruitment of Th1 lymphocytes, as observed in experimental paracoccidioidomycosis ${ }^{35}$. Besides, other authors have recently demonstrated high expression of the CTLA-4 (cytotoxic T lymphocyte antigen 4) receptor, a critical down regulator of $\mathrm{T}$ cell activation, and an increase in apoptosis mediated by Fas-Fas ligand from peripheral blood mononuclear cells of patients with Paracoccidioidomycosis ${ }^{14}$.

Complementary findings about NO production in oral cavity showed a reduced salivary NO levels in smokers ${ }^{9,17,25}$. This effect is attributed to iNOS down-regulation by the high NO concentration in smoke ${ }^{17}$. Although smoking status seem to contribute to the oral NO production, it was not investigated in our control patients or with OP, and other studies are still needed to confirm it. 
BATISTA, A.C.; SOARES, C.T. \& LARA, V.S. - Failure of nitric oxide production by macrophages and decrease in CD4+ T cells in oral paracoccidioidomycosis: possible mechanisms that permit local fungal multiplication. Rev. Inst. Med. trop. S. Paulo, 47(5): 267-273, 2005.

Besides the data referring to the comparisons among the subgroups must be interpreted with caution due to the limited number of samples evaluated, our findings suggest that low expression of iNOS by macrophages in OP samples and the decrease in the $\mathrm{CD}^{+} \mathrm{T}$ cells in OP samples with higher numbers of viable yeast cells may be associated with local fungal multiplication and maintenance of active oral lesions. However, further investigation is needed to confirm our hypothesis.

\section{RESUMO}

Falha na produção de óxido nítrico pelos macrófagos e diminuição de células $\mathrm{T} \mathrm{CD4}^{+}$na paracoccidioidomicose bucal: possíveis mecanismos que permitem a multiplicação fúngica local

A paracoccidioidomicose é uma doença granulomatosa crônica que induz resposta inflamatória e imune específica. A participação do óxido nítrico (NO), produto da enzima óxido nítrico sintase induzível (iNOS), como uma importante molécula fungicida contra o fungo Paracoccidioides brasiliensis tem sido demonstrada. Com o objetivo de melhor caracterizar as lesões orais da paracoccidioidomicose (OP), propusemos estudo imunohistoquímico das células iNOS ${ }^{+}$e das células

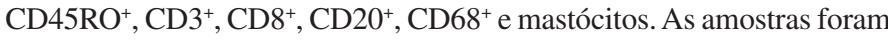
distribuídas em grupos de acordo com o número de fungos viáveis por $\mathrm{mm}^{2}$. Nossos resultados demonstraram leve imunomarcação para iNOS nas células gigantes multinucleadas (MNGC) e na maioria das células mononucleares $(\mathrm{MN})$, e a proporção de células MN/MNGC iNOS ${ }^{+}$na OP foi comparável a do grupo Controle (tecido bucal clinicamente saudável). Adicionalmente, nossa análise revelou similaridade no número de células $\mathrm{CD}_{4}^{+}$entre o Controle e o grupo de $\mathrm{OP}$ com elevado número de fungos. Estes achados sugerem que a baixa expressão de iNOS e a diminuição de células $\mathrm{CD}^{+}$na OP podem representar possíveis mecanismos que permitiram a multiplicação local do fungo e a manutenção das lesões bucais ativas.

\section{ACKNOWLEDGMENTS}

This work was supported by grants from the Fundação de Amparo à Pesquisa do Estado de São Paulo (FAPESP- 98/13274-0 and 01/019646) and the Conselho de Aperfeiçoamento de Pessoal de Nível Superior (Capes). We thank Dr. Ana Paula Campanelli (Department of Microbiology and Immunology, Bauru Dental School, University of São Paulo, Brazil) and Dr. Tarcília Aparecida Silva (Department of Pathology, Faculty of Medicine, University of Brasília, Brazil) for helpful suggestions and critical review of the manuscript. We thank José Roberto Pereira Lauris for his help with statistical analysis.

\section{REFERENCES}

1. ALBINA, J.E.; ABATE, J.A. \& HENRY Jr., W.L. - Nitric oxide production is required for murine resident peritoneal macrophages to suppress mitogen-stimulated $\mathrm{T}$ cell proliferation. Role of INF- $\gamma$ in induction of the nitric oxide-synthesizing pathway. $\mathbf{J}$. Immunol., 147: 144-148, 1991.

2. ALMEIDA, O.P.; JORGE, J.; SCULLY, C. \& BOZZO, L. - Oral manifestations of paracoccidioidomycosis (South American blastomycosis). Oral Surg. Oral Med. Oral Path., 72: 430-435, 1991

3. ALMEIDA, S.R. \& LOPES, J.D. - The low efficiency of dendritic cells and macrophages from mice susceptible to Paracoccidioides brasiliensis in inducing a Th1 response. Braz. J. med. biol. Res., 34: 529-537, 2001.
4. BATISTA, A.C.; SILVA, T.A.; CHUN, J.H. \& LARA, V.S. - Nitric oxide synthesis and severity of human periodontal disease. Oral Dis., 8: 254-260, 2002.

5. BENARD, G.; ROMANO, C.C.; CACERE, C.R. et al. - Imbalance of IL-2, IFN-gamma and IL-10 secretion in the immunosuppression associated with human paracoccidioidomycosis. Cytokine, 13: 248-252, 2001.

6. BICALHO, R.N.; SANTO, M.F.D.; DE AGUIAR, M.C.F. \& SANTOS, V.R. - Oral paracoccidioidomycosis: a retrospective study of 62 Brazilian patients. Oral Dis., 7: 56-60, 2001.

7. BOCCA, A.L.; HAYASHI, E.E.; PINHEIRO, A.G. et al. - Treatment of Paracoccidioides brasiliensis-infected mice with nitric oxide inhibitor prevents the failure of cellmediated immune response. J. Immunol., 161: 3056-3063, 1998.

8. BOCCA, A.L.; SILVA, M.F.; SILVA, C.L.; CUNHA, F.Q. \& FIGUEIREDO, F. Macrophage expression of class II major histocompatibility complex gene products in Paracoccidioides brasiliensis-infected mice. Amer. J. trop. Med. Hyg., 61: 280287, 1999.

9. BODIS, S. \& HAREGEWOIN, A. - Significantly reduced salivary nitric oxide levels in smokers. Ann. Oncol., 5: 371-372, 1994.

10. BORGES-WALMSLEY, M.I.; CHEN, D.L.; SHU, X.H. \& WALMSLEY, A.R. - The pathobiology of Paracoccidioides brasiliensis. Trends Microbiol., 10: 80-87, 2002.

11. BRUMMER, E.; HANSON, L.H.; RESTREPO, A. \& STEVENS, D.A. - Intracellular multiplication of Paracoccidioides brasiliensis in macrophages: killing and restriction of multiplication by activated macrophages. Infect. Immun., 57: 2289-2294, 1989.

12. BRUMMER, E.; SUN, S.H.; HARRISON, J.L. et al. - Ultrastructure of phagocytosed Paracoccidioides brasiliensis in nonactivated or activated macrophages. Infect. Immun., 58: 2628-2636, 1990.

13. CALICH, V.L.G. \& KASHINO, S.S. - Cytokines produced by susceptible and resistant mice in the course of Paracoccidioides brasiliensis infection. Braz. J. med. biol. Res., 31: 615-623, 1998.

14. CAMPANELLI, A.P.; MARTINS, G.A.; SOUTO, J.T. et al. - Fas-Fas ligand (CD95CD95L) and cytotoxic T lymphocyte antigen-4 engagement mediate $\mathrm{T}$ cell unresponsiveness in patients with paracoccidioidomycosis. J. infect. Dis., 187: 1496$1505,2003$.

15. CANO, L.E.; CASINO, S.S.; ARRUDA, C. et al. - Protective role of gamma interferon in experimental pulmonary paracoccidioidomycosis. Infect. Immun., 66: 800-806, 1998.

16. CANO, L.E.; SINGER-VERMES, L.M.; COSTA, T.A. et al. - Depletion of CD8 ${ }^{+}$T cells in vivo impairs host defense of mice resistant and susceptible to pulmonary paracoccidioidomycosis. Infect. Immun., 68: 352-359, 2000.

17. CAROSSA, S.; PERA, P.; DOGLIO, P. et al. - Oral nitric oxide during plaque deposition. Europ. J. clin. Invest., 31: 876-879, 2001.

18. CUNHA, F.Q.; MONCADA, S. \& LIEW, F.Y. - Interleukin-10 (IL-10) inhibits the induction of nitric oxide synthase by interferon- $\gamma$ in murine macrophages. Biochem. Biophys. Res. Commun., 182: 1155-1159, 1992.

19. DING, A.; NATHAN, C.F.; GRAYEAR, J. et al. - Macrophage deactivating factor and transforming growth factor- $\beta 1,-\beta 2$ and $-\beta 3$ inhibit induction of macrophage nitrogen oxide synthesis by INF- $\gamma$. J. Immunol., 145: 940-944, 1990.

20. FACCHETTI, A.; VERMI, W.; FIORENTINI, S. et al. - Expression of inducible nitric oxide synthase in human granulomas and histiocytic reactions. Amer. J. Path., 154: $145-152,1999$.

21. GONZALEZ, A.; GREGORI, W.; VELEZ, D.; RESTREPO, A. \& CANO, L.E. - Nitric oxide participation in the fungicidal mechanism of gamma interferon-activated murine macrophages against Paracoccidioides brasiliensis conidia. Infect. Immun., 68: $2546-2552,2000$. 
BATISTA, A.C.; SOARES, C.T. \& LARA, V.S. - Failure of nitric oxide production by macrophages and decrease in CD4+ T cells in oral paracoccidioidomycosis: possible mechanisms that permit local fungal multiplication. Rev. Inst. Med. trop. S. Paulo, 47(5): 267-273, 2005.

22. KARHAWI, A.S.K.; COLOMBO, A.L. \& SALOMÃO, R. - Production of IFN-gamma is impaired in patients with paracoccidioidomycosis during active disease and is restored after clinical remission. Med. Mycol., 38: 225-229, 2000.

23. KASHINO, S.S.; FAZIOLI, R.A.; CAFALLI-FAVATI, C. et al. - Resistance to Paracoccidioides brasiliensis infection is linked to a preferential Th1 immune response, whereas susceptibility is associated with absence of INF- $\gamma$ production. $\mathbf{J}$. Interferon Cytokine Res., 20: 89-97, 2000.

24. KENDALL, H.K.; MARSHALL, R.I. \& BARTOLD, P.M. - Nitric oxide and tissue destruction. Oral Dis., 7: 2-10, 2001.

25. KHARITONOV, S.A.; ROBBINS, R.A.; YATES, D.; KEATINGS, V. \& BARNES, P.J. Acute and chronic effects of cigarette smoking on exhaled nitric oxide. Amer. J. resp. Crit. Care Med., 152: 609-612, 1995.

26. LOCKSLEY, R.M.; PINGEL, S.; LACY, D. et al. - Susceptibility to infectious diseases: Leishmania as a paradigm. J. infect. Dis., 179 (suppl. 2): S305-S308, 1999.

27. MAMONI, R.L.; NOUER, S.A.; OLIVEIRA, S.J. et al. - Enhanced production of specific IgG4, IgE, IgA and TGF-beta in sera from patients with the juvenile form of paracoccidioidomycosis. Med. Mycol., 40: 153-159, 2002

28. MARQUES MELLO, L.; SILVA-VERGARA, M.L. \& RODRIGUES, V. - Patients with active infection with Paracoccidioides brasiliensis present a Th2 immune response characterized by high interleukin-4 and interkeukin-5 production. Hum. Immunol., 63: $149-154,2002$

29. MOSCARDI-BACCHI, M.; SOARES, A.; MENDES, R.; MARQUES, S. \& FRANCO, M. - In situ localization of T lymphocytes subsets in human paracoccidioidomycosis. J. med. vet. Mycol., 27: 149-158, 1989.
30. MOTA, N.G.S.; REZKALLAH-IWASSO, M.T.; PERAÇOLI, M.T.S. et al. - Correlation between cell-mediated immunity and clinical forms of paracoccidioidomycosis. Trans. roy. Soc. trop. Med. Hyg., 79: 765-772, 1985.

31. NASCIMENTO, F.R.F.; CALICH, V.L.G.; RODRIGUEZ, D. \& RUSSO, M. - Dual role of nitric oxide in paracoccidioidomycosis: essential for resistance, but overproduction associated with susceptibility. J. Immunol., 168: 4593-4600, 2002.

32. NEWORAL, E.P.M.; ALTEMANI, A.; MAMONI, R.L.; NORONHA, I.L. \& BLOTTA M.H.S.L. - Immunocytochemical localization of cytokines and inducible nitric oxide synthase (iNOS) in oral mucosa and lymph nodes of patients with paracoccidioidomycosis. Cytokine, 21: 234-241, 2003.

33. OLIVEIRA, S.J.; MAMONI, R.L.; MUSATTI, C.C.; PAPAIORDANOU, P.M.O. \& BLOTTA, M.H.S.L. - Cytokines and lymphocyte proliferation in juvenile and adul forms of paracoccidioidomycosis: comparison with infected and non-infected controls. Microbes Infect., 4: 139-144, 2002.

34. SICHER, S.C.; VAZQUEZ, M.A. \& LU, C.Y. - Inhibition of macrophages Ia expression by nitric oxide. J. Immunol., 153: 1293-1300, 1994.

35. SOUTO, J.T.; ALIBERTI, J.C.; CAMPANELLI, A.P. et al. - Chemokine production and leukocyte recruitment to the lung of Paracoccidioides brasiliensis-infected mice is modulated by Interferon- $\gamma$. Amer. J. Path., 163: 583-590, 2003.

36. SOUTO, J.T; FIGUEIREDO, F.; FURLANETTO, A et al. - Interferon- $\gamma$ and tumo necrosis factor- $\alpha$ determine resistance to Paracoccidioides brasiliensis infection in mice. Amer. J. Path., 156: 1811-1820, 2000.

37. VAN DER VEEN, R.C.; DIETLIN, T.A.; PEN, L. \& GRAY, J.D. - Nitric oxide inhibits the proliferation of T-helper 1 and 2 lymphocytes without reduction in cytokine secretion. Cell Immunol., 193: 194-201, 1999.

Received: 8 September 2004

Accepted: 21 July 2005 